\title{
CARRIAGE OF INHIBITOR-PRODUCING ORGANISMS ON HUMAN SKIN
}

\author{
W. C. NoBle AND JeANETte A. Willie \\ Department of Bacteriology, Institute of Dermatology, Homerton Grove, London E9 $6 B X$
}

SELWYN (1975) described the carriage of antibiotic-producing organisms on human skin and showed how they might protect the carrier against colonisation with potential pathogens such as Staphylococcus aureus. Subsequent work by Selwyn and his colleagues (Marsh and Selwyn, $1977 a$ and $b$; Milyani and Selwyn, 1978) has shown that these antibiotic producers can restrict the growth of susceptible strains in vitro. This paper reports a study of the carriage, in patients with skin disease, of "antibiotic"-producing cocci with an activity against $S$. aureus.

\section{MATERIALS AND METHODS.}

Samples for bacterial culture were taken from the nose, the chest, the perineum and one or more lesions of patients admitted to the Inpatient Department of St John's Hospital for Diseases of the Skin; cotton-tipped swabs moistened with broth were used. When $S$. aureus was isolated from a skin lesion the opinion of a clinician, usually the senior house officer, was sought on whether the lesion was clinically infected or only colonised; these opinions were recorded. The swabs were inoculated on to Blood Agar Base (Oxoid CM55) used as a 'nutrient' agar and the plates were incubated aerobically for $24 \mathrm{~h}$ at $37^{\circ} \mathrm{C}$ and left on the bench for a further $24 \mathrm{~h}$ at ambient temperature. A semi-quantitative assessment was made of each colony type present.

Representatives of all colony types were subcultured on to blood-agar-base plates under a serial code number and examined for production of inhibitors. In the initial studies on about 4000 isolates, the method used was a modification of a pyocine typing method (Darrell and Wahba, 1964) in which test strains were inoculated as a heavy streak across the diameter of a glass petri dish containing blood-agar-base medium. This plate was then incubated for $24 \mathrm{~h}$, after which the growth was removed by scraping with a microscope slide and the plate was exposed to chloroform vapour for $10 \mathrm{~min}$. After exposure to air to permit evaporation of residual chloroform, four indicator strains were inoculated at right angles to the site of the original culture. The plates were then reincubated for $24 \mathrm{~h}$ at $37^{\circ} \mathrm{C}$. Antibiotic production was indicated by a failure of growth in the area from which the test strain had been removed.

Another 1300 isolates were tested by a modification of this method in which, after removal of the test-isolate growth with a glass microscope slide, any remaining cells were spread over the surface of the medium with a cotton tipped swab ('Q-tip') moistened in broth. The plate was then exposed to ultraviolet light for $20 \mathrm{~min}$. to kill remaining cells; four indicator strains were then applied as previously described.

The indicator strains used were $S$. aureus PS80, the original epidemic strain which remains virulent for mice and is used for propagating phage $80 ;$ S. aureus PS 42E, the propagating strain for phage 42E; S. aureus Wood 46, the standard $\alpha$-haemolysin producer; and Micrococcus luteus $27 B$, a wild-type isolate from a patient.

\section{RESULTS}

From 292 patients, 5282 strains were tested. Inhibitor producers active against $S$. aureus were found in about $5 \%$ of sites (table I) or about $10 \%$ of persons. Only $1.6 \%$ of strains tested were producer organisms. The prevalence of producer organisms was approximately the same 
TABLE I

Isolation of "antibiotic"-producer organisms from carrier sites and lesions

\begin{tabular}{l|cc}
\hline Site & $\begin{array}{c}\text { Number of persons } \\
\text { sampled }\end{array}$ & $\begin{array}{c}\text { Number (and percentage) } \\
\text { yielding producer organisms }\end{array}$ \\
\hline Nose & 260 & $8(3)$ \\
Chest & 292 & $17(5 \cdot 5)$ \\
Groin & 291 & $14(4 \cdot 5)$ \\
Lesion & 295 & $24(8)$ \\
\hline
\end{tabular}

* Overgrowth of plates by Proteus resulted in loss of some samples.

in lesions that were only colonised and those that were clinically infected with $S$. aureus (table II). Table III shows that the proportion of skin lesions yielding antibiotic producers was only slightly greater in those yielding no pathogens (S. aureus, Streptococcus pyogenes, Proteus or Pseudomonas) than in those yielding $S$. aureus and other pathogens.

When present, the producer organisms were the dominant flora in $30 \%$ of cultures and a minority flora in $25 \%$; in the remainder the producer and other organisms were present in about equal numbers. There was no difference in the proportion of producer organisms identified by the two methods.

\section{TABLE II}

Colonisation and clinical infection with Staphylococcus aureus in relation to presence or absence of antibiotic producers in sk in lesions

\begin{tabular}{l|cc}
\hline & \multicolumn{2}{|c}{$\begin{array}{c}\text { Number (and percentage) of skin } \\
\text { lesions }\end{array}$} \\
$\begin{array}{l}\text { Antibiotic } \\
\text { producers }\end{array}$ & $\overbrace{\text { colonised only clinically infected }}$ \\
\hline $\begin{array}{l}\text { present } \\
\text { absent }\end{array}$ & $63(7 \cdot 4)$ & $6(7 \cdot 2)$ \\
\hline Total & 68 & 77 \\
\hline
\end{tabular}

\section{Discussion}

The prevalence of inhibitor producers in the isolates examined in this series appears to be low. Hsu and Wiseman (1967) reported that $4.9 \%$ of 1065 isolates of $S$. aureus and $8.5 \%$ of 387 coagulase-negative cocci produced antibiotics active against the Oxford strain of $S$. aureus. In contrast, Selwyn (1975) found that isolates from $22.6 \%$ of 340 persons produced antagonists when tested against coagulase-negative staphylococci and coryneforms (Selwyn and Ellis, 1972). Holland, Cunliffe and Eady (1979) found antagonists produced by skin Micrococcaceae in

TABLE III

Presence of $S$. aureus and other pathogens in relation to presence or absence of antibiotic producers

\begin{tabular}{l|cc}
\hline $\begin{array}{l}\text { Antibiotic } \\
\text { producers }\end{array}$ & $\begin{array}{c}\text { yielding } S \text {. aureus or } \\
\text { other pathogens }\end{array}$ & $\begin{array}{c}\text { not yielding } S \text {. aureus or } \\
\text { other pathogens }\end{array}$ \\
\hline $\begin{array}{l}\text { present } \\
\text { absent }\end{array}$ & $\begin{array}{r}9(7 \cdot 1) \\
118\end{array}$ & $\begin{array}{c}15(8 \cdot 3) \\
166\end{array}$ \\
\hline Total & 127 & 181 \\
\hline
\end{tabular}


$15 / 148(10 \%)$ isolates tested from 44 persons but by $38 / 93$ (41\%) of Propionibacterium acnes from the same individuals. However, only $2.7 \%$ of the Micrococcaceae would inhibit other Micrococcaceae, whereas $41 \%$ of the $P$. acnes were active against other P. acnes. Holland and his colleagues reported that media containing $0.5 \%$ glucose, such as that used by Selwyn, can lead to the appearance of inhibition solely as a result of acid production. They are careful to emphasise that not all "inhibition" or "antagonism" observed on agar medium is the result of antibiotic production. The low rates of producer strains in the present series and in those of Hsu and Wiseman (1967) and Holland et al. (1979) when compared with the findings of Selwyn (1975) thus seem referable to the more stringent test (Jiditions when media containing only small amounts of glucose are used. Antibiotics produced by Micrococcaceae are polypeptides (Halbert, Swick and Sonn, 1953; Hsu and Wiseman, 1972).

Selwyn (1975) was able to show a reduction in colonisation by pathogens of lesions containing producer organisms, but in this series no difference in colonisation or in clinical infection could be detected. Experimental studies of our own (unpublished data) show that inhibition, presumably due to antibiotic production, is caused by producer organisms against indicator strains on the skin surface of the hairless/obese mouse (J. Atkinson, in preparation) and in a subcutaneous model of infection (Noble, 1965). This confirms the observations of Selwyn and his colleagues on in-vitro antagonism in various experimental situations (Marsh and Selwyn, 1977a and $b$; Milyani and Selwyn, 1978). Dr T. Sethna and Dr S. Selwyn (personal communication) have demonstrated in-vivo antagonism. Nevertheless it is difficult to assess the likelihood of antibiotic production in vivo in the human host. If production occurred it would seem to imply that producer organisms should be the dominant form, because producer strains should outgrow non producers, yet this occurred in only $30 \%$ of instances in this series. Youssef et al. (1979) showed that dermatophyte fungi produced detectable amounts of antibiotic, in this case penicillin-like substances, in only 4 of $\mathbf{4 5}$ patients, although these four strains represented $16 \%$ of the 25 fungi able to produce such antibiotics in vitro. In Youssef's series temperature was found to be of importance in antibiotic production in vitro. We do not yet know the precise conditions in which organisms grow at the skin surface; such knowledge would be of immense value in assessing the skin as a microbial habitat and in deciding whether antibiotic production in situ could be put to therapeutic use.

\section{SUMMARY}

The carriage on skin lesions, on healthy skin and in the nose, of micro-organisms that produce antibiotics active against Staphylococcus aureus has been studied. About $5 \%$ of sites ( $10 \%$ of all patients) yielded such organisms. No evidence could be found that the presence of producer organisms in skin lesions had a protective effect against colonisation by $S$. aureus.

We are indebted to the Medical Research Council for supporting this investigation and to the consultant staff of St John's Hospital for Diseases of the Skin for permission to study patients in their care. Dr S. Selwyn is thanked for making available his standard antibiotic-producing strain of $S$. epidermidis for comparison.

\section{REFERENCES}

Darrell, J. H. AND Wahba, A. H. 1964. Pyocine-typing of hospital strains of Pseudomonas pyocyanea. J. clin. Path., 17, 236.

HALBERT, S. P., SWICK, L. AND SONN, C. 1953. Characteristics of antibiotic-producing strains of the ocular bacterial fiora. J. Immunol., 70, 400 .

Holland, K. T., Cunliffe, W. J. and Eady, E. A. 1979. Intergeneric and intrageneric inhibition between strains of Propionibacterium acnes and Micrococcaceae, particularly Staphylococcus epidermidis, isolated from normal skin and acne lesions. J. med Microbiol., 12,71 .

Hsu, C-Y. and Wiseman, G. M. 1967. Antibacterial substances from staphylococci. Can.J. Microbiol., 13, 947. 
Hsu, C-Y. And Wiseman, G. M. 1972. The nature of epidermidins, new antibiotics from staphylococci. Can J. Microbiol., 18, 121.

Marsh, P. D. AND SelwyN, S. 1977a. Studies on antagonism between human skin bacteria. $J$. med. Microbiol., 10, 161.

MARSH, P. D. AND SELWYN, S. 1977b. Continuous-culture studies of interactions among human skin-commensal bacteria. J. med. Microbiol., 10, 261.

Milyani, R. M. AND Selwyn, S. 1978. Quantitative studies on competitive activities of skin bacteria growing on solid media. J. med. Microbiol., 11, 379.

NOBLE, W. C. 1965. The production of subcutaneous staphylococcal skin lesions in mice. $B r$. J. exp. Path., 46, 254.

SELWYN, S. 1975. Natural antibiosis among skin bacteria as a primary defence against infection. Br. J. Derm., 93, 487.

SelwyN, S. AND Ellis, H. 1972. Skin bacteria and skin disinfection reconsidered. Br. med.J., $1,136$.

Youssef, N., Wyborn, C. H. E., Holt, G., Noble, W. C. and Clayton, Y. M. 1979. Ecological effects of antibiotic production by dermatophyte fungi. J. Hyg., Camb., 82, 301. 